\title{
PENINGKATAN KETERAMPILAN DASAR KONSELING DENGAN BIMBINGAN KELOMPOK BAGI MAHASISWA PGSD FKIP UNIVERSITAS MATARAM
}

\author{
A. Hari Witono ${ }^{1}$, I Ketut Widiada ${ }^{1}$, Mansur Hakim ${ }^{1}$, Abd. Kadir Jaelani ${ }^{2}$, Heri Setiawan ${ }^{1 *}$ \\ ${ }^{1,2}$ PGSD FKIP Universitas Mataram \\ ${ }^{2}$ PG-PAUD FKIP Universitas Mataram \\ *Corresponding Author: heri_setiawan@unram.ac.id
}

\section{Article History}

Received : January $24^{\text {th }}, 2021$

Revised : February $20^{\text {th }}, 2021$

Accepted : March $13^{\text {th }}, 2021$

Published : May $05^{\text {th }}, 2021$

\begin{abstract}
Abstrak: Keterampilan dasar konseling adalah modal awal bagi individu pembimbing. Penelitian ini bertujuan untuk meningkatkan keterampilan dasar konseling dengan bimbingan kelompok. Pemilihan tindakan intervensi berbasis kelompok dilakukan karena pada umumnya mahasiswa memiliki karakteristik masih sangat menyenangi untuk berinteraksi dengan kelompok. Penelitian ini menggunakan metode kuantitatif jenis Penelitian Tindakan Kelas (action research) dengan menerapkan system siklus. Tindakan dilakukan terhadap 9 orang mahasiswa PGSD FKIP Universitas Mataram tingkat akhir, yang diambil secara acak, diberi layanan bimbingan kelompok pada siklus I dan Siklus II. Analisis data dilakukan dengan menggunkan model mixed analysis (perpanduan antara analisis kuantitatif dan kualitatif). Hasil penelitian menunjukkan bahwa pada siklus I diperoleh skor rata-rata adalah 28,5 $(64,90 \%)$, rata-rata berada pada kategori sedang dan pada siklus II skor rata-rata adalah $32(74,24 \%)$, berada pada kategori tinggi. Data ini menunjukkan kenaikan sebesar 9,34\%. Dengan demikian, hipotesis tindakan yang diajukan: "Jika bimbingan kelompok dilaksanakan dengan benar, maka keterampilan dasar konseling mahasiswa meningkat" terbukti kebenarannya. Rekomenasi hasil penelitian ini yaitu pemanfaatan dan adopsi model bimbingan kelompok agar dijakikan sebagai kebijakan oleh pihak terkait.
\end{abstract}

Keywords: Bimbingan kelompok, Keterampilan dasar konseling, Mahasiswa.

\section{PENDAHULUAN}

Keterampilan dasar konseling adalah modal awal bagi individu pembimbing, dalam konteks ini bagi guru sebagai pendidik dalam melaksanakan pekerjaan profesionalnya sebagai pendidik, sebagai tugas pengiring dengan pembelajaran peserta didik di sekolah. Terlebih tugas membimbing kian terasa, ketika guru itu bertugas di Sekolah Dasar. Sebab di satuan Pendidikan dan jenjang ini guru dituntut selain mengajar juga dibebani tugas bimbingan kepada siswa yang menjadi tanggungjawabnya. Dinyatakan bahwa dalam SK Menpan No. 084/1993 pasal 3 tentang jabatan fungsional guru dan angka kreditnya, bahwa tugas guru, terutama di SD yaitu menyusun program bimbingan, melaksanakan program bimbingan dan evaluasi pelaksanaan bimbingan, analisis hasil pelaksanaan bimbingan dan tindak lanjut program bimbingan dan terhadap peserta didik yang menjadi tanggumg jawabnya

Mahasiswa PGSD sebagai calon guru di dalam melaksanakan tugas profesionalnya secara preservice dalam pembelajaran di LPTK dan di Kurikulum pada umumnya hanya dibekali dengan 2 SKS Mata kuliah Bimbingan Konseling (BK). Dengan kata lain, hanya dibekali dengan kemampuan minimal (berupa pengetahuan dan keterampilan umum BK) yang sifatnya sangat umum, tidak mendasar dan tidak "menyentuh" kepada penguasaan dan keterampilan teknis berupa konseling (baik individual maupun kelompok). Tiba gilirannya dapat diduga dan sekaligus terbukti para mahasiswa dan Lulusan PGSD akan kurang memahami praksis bimbingan dan konseling secara benar. Terlebih juga tidak memahami dan tidak dapat melaksanakan konseling kepada siswa.

Temuan diatas sebagaimana diungkap dari hasil penelitian A.Hari Witono, I Ketut 
Widiada, dan Niswatul Khoir (2018; 37) bahwa sebagian besar guru-guru SD lebih 60\% tidak berpartisipasi dalam pelaksaaan BK di sekolah. Diungkap lebih jauh, mengapa tidak melakukan bimbingan tugas sebagai tugas samping pembelajaran (auxalary) tersebut, sebagai jawabnnya adalah mereka tidak memahami bagaimana melakukannya. Bahkan tidak mengetahui aspek-aspek apa saja yang termasuk membimbing siswa tersebut. Diungkap juga dari penelitian itu, ternyata sebagian besar guru ( $80 \%$ dari populasi ) menyatakan bahwa di sekolah jenjang SD jarang sekali bahkan tidak pernah dilaksanakan semacam pelatihan (inservice training) tentang Ke-BK an dari Depdiknas, atau dari LPMP sebagai Lembaga peningkatan kinerja guru.

Melihat dan memperhatikan kondisi riil di lapangan sebagaimana diuraikan tersebut, maka perlu ada upaya-upaya terutama dari LPTK, seperti FKIP sebagai Lembaga penghasil guru untuk mengantisipasi sejak dini agar para calon guru tidak menghadapi masalah dalam tugasnya, yaitu melaksankan BK di sekolah setelah mereka menamatkan pendidikannya kelak kemudian hari. Salah satu alternative tindakan preventif dimaksud ialah perlu dilakukan penelitian untuk meningkatkan keterampilan dasar konseling mahasiswa PGSD. Mengingat keterampilan konseling dasar diyakini sebagai keterampilan inti dari layanan BK. Tanpa keterampilan ini Guru dalam praktiknya tidak dapat melakukan perannya sebagai pembimbing dengan baik. Tanpa keterampilan konseling sebagai helper guru tidak akan dapat membantu konseli atau siswa yang bermasalah dalam pekerjaannya sehari-hari.

Di tengah-tengah kesibukannya belajar di kampus, mahasiswa yang diteliti (sebagai upaya peningkatan kemampuan dan keterampilan dasar konselingnya) perlu dicarikan strategi penelitian yang tidak mengganggu aktivitas mereka terlibat dalam pembelajaran. Oleh sebab itu penelitian yang ditawarkan disini adalah model Penelitian Tindakan Kelas (PTK). Artinya, diharapkan dengan strategi penelitian model demikian, mahasiswa tidak akan banyak terganggu dengan keterlibatannya sebagai subjek penelitian. Teknik yang digunakan untuk peningkatan keterampilan dasar konseling mahasiswa dimaksud yang dipilih peneliti ialah dengan bimbingan kelompok.

Ada beberapa alas an mendasar mengapa bimbingan kelompok digunakan sebagai langkah dan strategi untuk meningkatkan ketrampilan mahasiswa melakukan konseling tingkat dasar. Alasan pertama, ialah adanya konsep yang mendasari bahwa pada hakikatnya manusia itu pada nalurinya senang hidup berkelompok. Alasan kedua. Alas an teknis bahwa mahasiswa di kelompok itu, telah sangat mengenali peneliti (konsekuensi peneliti sebagai dosen bagi subjek) sehingga akan lebih mudah mengkondisikan, dan ketiga alas an pragmatis dari penelitianpenelitian terdahulu, yang membuktikan bahwa bimbingan kelompok ,ternyata efektif digunakan untuk merubah tingkah laku (behavior modification), bahkan efektif juga untuk meningkatkan hasil belajar siswa. Contoh dua diantaranya penelitian dilakukan oleh : N W Heny Purwanita, N Dantes, N M Setuti (2017:1), Nindia Harnes Prima Aidha (2014: 1) diungkap bahwa bimbingan kelompok dapat berfungsi secara efektif untuk meningkatkan motivasi belajar siswa.

Keterampilan dasar konseling, menyangkut pemguasaan konsep dan keterampilan komunikasi yang berbasis pemberikan bantuan kepada orang lain (helping to others); antara lain membuka konseling, inti konseling dan penutup layanan konseling. Atas dasar pemikiran sebagaimana baru saja diuraikan maka penelitian ini dilakukan sebagai upaya untuk menemukan jawaban atas hipotesis tindakan yang diajukan bahwa jika bimbingan kelompok dilakukan dengan benar maka keterampilan dasar konseling pada mahasiswa PGSD akan meningkat.

\section{METODE}

Penelitian ini menggunakan metode kuantitatif jenis Penelitian Tindakan Kelas (action research) dengan menerapkan system siklus. Tindakan dilakukan terhadap 9 orang mahasiswa PGSD FKIP Universitas Mataram tingkat akhir, yang diambil secara acak, diberi layanan bimbingan kelompok pada siklus I dan Siklus II (Rahmawati, 2016:4; Sukmawati et al, 2013:12; Setiawan et al, 2020). Selama pelaksanaan tindakan peneliti, didampingi oleh obsever untuk melihat proses pelaksanaan bimbingan kelompok yang dilakukan peneliti, yang pada akhirnya hasil observasinya digunakan untuk perbaikan rencana dan tindakan pada siklus berikutnya. Penelitian bertempat di Kampus 2 Universitas Mataram dan 
dilaksanakan pada bulan Juli - September 2020. Ada dua jenis instrument yang digunakan dalam penelitian ini. Tes Katerampilan dasar Konseling, dan instumen perlakuan yang disusun peneliti berupa Rencana Pelaksanaan Tindakan Bimbingan Kelompok (RPTBK) (Sukmawati et al, 2013:13). Sekor-sekor hasil penelitian dianalisis dengan metode Analisis statistic deskriptif, persentasional.

\section{HASIL DAN PEMBAHASAN}

\section{Gambaran Keterampilan Dasar Konseling Mahasiswa Dengan Bimbingan Kelompok}

Sesuai dengan langkah-langkah yang jelaskan sebelumnya, Metode penelitian, maka diperoleh data hasil penelitian. Data dimaksud berupa skor mentah berupa angka-angka sebagai hasil dari Tes Kemampuan dasar Konseling (TKDK) yang telah divalidasi sebelumnya. Selain, itu juga ada data kualitatif berupak katakata atau kalimat yang diungkap responden, sebagai data pelengkap dan pendukung dari data kuantitatif yang diperoleh sebelumnya. Secara implisit, ada data hasil observasi dari observer sebagai bahan masukan perbaikan akan rencana tindakan peneliti yang akan dirumuskan untuk dilakukan pada tindakan berikutnya (dikenal dengan Siklus). Untuk keperluan laporan ini data hanya disajikan dalam bentuk angka atau skor masing-masing siklus, yaitu siklus I dan siklus II. Berikut data kualitatif, berupa hasil wawancara akan disajikan pada pembahasan sebagai penguat data kuantitatif sebagai hasil intervensi masingmasing siklus. Data kuantitatif hasil pensekoran sebagai hasil tindakan masing-masing siklus tersebut dapat disajikan dalam Tabel berikut ini.

Table 1 Data Skor Mentah dan Persentase hasil intervensi Siklus I dan Sklus II.

\begin{tabular}{cccccc}
\hline No. & $\begin{array}{c}\text { Subyek } \\
\text { (Samaran) }\end{array}$ & Siklus I & Pesentase & Siklus II & Persentase \\
\hline 1 & AUL & 32 & 72.73 & 36 & 81.82 \\
2 & FIT & 32 & 72.73 & 33 & 75.00 \\
3 & HUD & 25 & 56.82 & 27 & 61.36 \\
4 & IRAP & 25 & 56.82 & 27 & 61.36 \\
5 & IZUM & 38 & 86.36 & 42 & 95.45 \\
6 & LIR & 25 & 56.82 & 30 & 68.18 \\
7 & LYA & 24 & 54.55 & 28 & 63.64 \\
8 & LDIM & 28 & 63.64 & 30 & 68.18 \\
9 & LEVA & 28 & 63.64 & 41 & 93.18 \\
\hline & Rata-rata & 28.55556 & 64.90 & 32.66667 & 74.24 \\
\hline
\end{tabular}

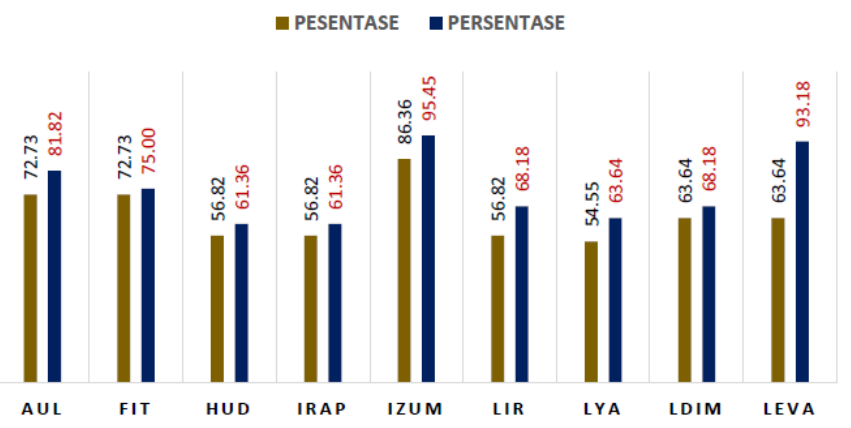

Gambar 1 :Perkembangan Persentase Subjek Penelitian sebagai dampak Bimbingan kelompok Siklus I dan Siklus I

Pembahasan Data Hasil Pemetaan Keterampilan Dasar Konseling Mahasiswa Dengan Bimbingan Kelompok

Melihat gambar 1 tersebut, tampak jelas bahwa rata-rata umum, sekor dan persentase semua subjek penelitian, mengalami peningkatan pada siklus I ke siklus II. Jika dilihat masingmasing individu, peningkatan yang paling tinggi terlihat pada subje bernama LEVA (samaran). Pada siklus I memperoleh persentase 63,64\% sedangkan pada siklus II meningkat tajam menjadi 93,18\%. Dengan kata lain, LEVA 
memperoleh manfaat $29,54 \%$ dari intervensi bimbingan kelompok. Sedangkan peningkatan paling kecil terjadi pada subjek nama FIT, dimana pada siklus I memperoleh pessentase 72,73\% dan pada siklus II memperoleh 75,00\%. Dengan kata lain keterampilan dasar konseling subjek bernama FIT (samaran) hanya meningkat $2,27 \%$, atau dapat diartikan bahwa FIT hanya memperoleh manfaat $2,27 \%$ dari intervensi bimbingan kelompok yang dilakukan peneliti.

Perolehan sekor rata-rata dari semua subjek penelitian, dari 9 orang mahasiswa PGSD FKIP Universitas Mataram sebagaimana diuraikan tersebut di atas, selanjutkan dapat dimasukkan kedalam kategori interval (Hadi, 1986:12). Sebagai hasil perhitungan tersebut sebagaimana terlihat dalam Tabel 4.2 telah terbukti bahwa pada siklus I dari semua subjek penelitian diperioleh skor rata-rata 28.5, dan pada Siklus II diperoleh rata-rata sekor 32.6. Rata-rata sekor tersebut jika dikonsultasikan ke dalam table 4.3, interval skor dan kategori kualitas hasil intervensi diperoleh makna Ternyata pada siklus I diperoleh rerata skor 28,5 berada pada interval III, (yaitu berada pada interval diantara 27,3 $30,8)$ yaitu kategori Sedang. Sedang perolehan siklus II rata-rata subyek memperoleh skor 32,66, berada pada interval II, (yaitu berada di antara skor 30,9 - 34,4) kategori Tinggi. Dengan demikian dapat dinyatakan bahwa intervensi bimbingan kelompok yang diberikan peneliti pada siklus I, subjek hasilnya masih berada kategori sedang. Setelah dilakukan perbaikan intervensi pada siklus II, hasilmya terjadi peningkatan pada masing-masing subjek penelitian yang rata-rata menjadi berkategori tinggi.

Sebagaimana telah diungkap dalam penelitian ini, bahwa bimbingan kelompok yang dilakukan peneliti terhadap 9 orang subjek penelitian, mahasiswa prodi PGSD Semester VII FKIP Universitas mataram, dengan tindakan bimbingan kelompok sebanyak 2 (dua) siklus, menunjukkan hasil yang positif dengan peningkatan keterampilan subjek penelitian yang cukup signifikan (periksa Tabel 4.2). Artiya, persentase atau kualitas keterampilan dasar konseling mahasiswa yang semula hanya berkategori sedang, ternyata setelah dilakukan tindakan secara siklikal keterampilan mereka meningkat, dari kategori sedang menjadi tergolong berkategori tinggi (dengan peningkatan rata-rata sebesar 9,35\% ). Temuan ini dapat diartikan bahwa bimbingan kelompok efektif digunakan untuk meningkatkan keterampilan dasar konseling mahasiswa.

Hasil penelitian ini ternyata menguatkan hasil penelitian yang telah dilakukan peneliti terdahulu, antara lain, Ayyub (2011: 1286), Bilge, Y (2017: 72), dan Tanjung, Yoppy; Budi Astuti; dan Andika Arisandi (2019: 377). Semua penelitian tersebut mengungap bahwa bimbingan kelompok efektif untuk meningkatkan perilaku indivisu. Pertanyaan selanjutnya di sini ialah mengapa begitu kuat pengaruhnya pelaksanaan bimbingan kelompok terhadap pembentukan perilaku individu, dalam hal ini bimbingan kelompok sebagai sarana peningkatan keterampilan dasar konseling mahasiswa FKIP Universitas Mataram. Sebagai jawabannya secara teoritik dapat dijelaskan bahwa kohesivitas kelompok merupakan penyokong terbentuknya perilaku baru individu. Secara kondisional, individu mampu belajar dari lingkungan, lingkungan yang nyaman dan bagaimana lingkungan memberikan contoh terhadap diri individu itu, apa yang dilihat individu menjadi model (modelling), dipelajari yang selanjutnya model perilaku tersebut dilakukan dalam kehidupan sehari-hari menjadi perilaku baru dan akhirnya merupakan menjadi kebiasaan dan mempribadi Albert Bandura, dalam Muliati (2019).

\section{KESIMPULAN}

Proses Bimbingan Kelompok yang dilakukan dalam penelitiaan ini merujuk langkah-langkah sebagimana tertuang dalam Rencana Pelaksanaa Tindakan Bimbingan Kelompok (RPTBK), yang didampingi oleh observer untuk melihat proses kekurangan dan kelebihan peneliti dalam melaksanakan bimbingan kelompok baik dalam siklus I mapun siklus II. Siklus I diperoleh rata-rata kemampuan mahasiswa 64.90. Siklus II menunjukkan adanya peningkatan rata-rata sebesar 74.24. Dengan persentase peningkatan (tindakan siklus I ke siklus II) dari semua subjek penelitian rata-rata meningkat sebesar 9,34\%. Dalam hal ini diperoleh gambaran peningkatan keterampilan pembimbingan dasar konseling mahasiswa. Simpulan penting lainnya ialah keterampilan bimbingan kelompok jika dilaksanakan dengan benar, melalui tahap-tahap sebagai berikut; tahap pembentukan, tahap peralihan, tahap kegiatan dan tahap pengakhiran maka akan dapat digunakan untuk meningkatkan keterampilan dasar konseling mahasiswa prodi PGSD FKIP 
Unram. Keterampilan dasar dimaksud menyangkut bagian awal atau prakondisi; bagian inti (proses); dan bagian akhir.

Atas dasar simpulan hasil penelitian tersebut di atas, maka selanjutnya dapat dibuat saran. Saran diajukan kepada pihak-pihak sebagai berikut: (1). Lembaga FKIP Universitas Mataram, terutama prodi PGSD mengadakan berbagai pelatihan yang sifatnya kelompok; seperti bimbingan kelompok, dinamika kelompok dll. Pelatihan-pelatihan tersebut, diutamakan yang berhubungan dengan peningkatan pengetahuan dan keterampilan lain, terkait dengan bimbingan konseling sebagai bekal mahasiswa dalam menjalankan fungsinya sebagai pembimbing siswa setelah ia menjadi guru professional kelak kemudian hari; (2). Kepada Dinas Pendidikan, termasuk LPMP (Lembaga Penjaminan Mutu Pendidikan ) Nusa tenggara Barat umumnya, dan Dinas Pendidikan dan Kebudayaan Kota Mataram pada khususnya. Oleh karena, selama ini guru-guru SD tidak memahami dan kurang terampil melaksanakan konseling, sebagai akibat dari kurangnya persiapan pengetahuan dan keterampilan di bidang ini (ketika masih kuliah) maka disarankan untuk dilaksanakan berbagai 'pelatihan (inservice training) tentang ke BK an. Sebagaimana telah terbukti, sarana yang dapat digunakan adalah bimbingan kelompok; (3) Kepada mahasiwa PGSD FKIP Universitas mataram, terutama pengurus BEM FKIP dan HMPS PGSD. Karena penelitian ini telah membuktikan bahwa ternyata keterampilan dasar konseling dapat ditingkatkan dengan bimbingan kelompok, hendaknya ditumbuhsuburkan kegiatan, yang bernuansa kelompok (peer group) di berbagai kesempatan, selain kuliah tersetruktur bersifat regular. Kegiata-kegiatan lain yang menunjang peningkatan kompetensi sebagai bekal akademik yang tidak diperoleh dalam perkuliahan, seperti layanan konseling ini hendaknya juga memperoleh perhatian; (4). Kepada peneliti lain, yang tertarik dikajian bimbingan konseling umumnya dan pengubahan perilaku pada khsusunya, diharapkan hasil penelitian ini dapat digunakan sebagai pijakan dalam mengembangkan kajian bimbingan konseling bagi mahasiswa calon guru, terutama calon guru sekolah dasar. Sehingga, kajian-kajian bimbingan konseling yang berbasis ke SD an akan makin marak di bumi tanah air, Indonesia.

\section{UCAPAN TERIMA KASIH}

Ucapan terima kasih atas dukungan pendanaan PNBP dari dana DIPA BLU Universitas Mataram Tahun anggaran 2020, dengan nomor kontrak Surat Perjanjian Nomor 2618/UN18.1.1/PP/2020. Ucapan terimakasih juga disampaikan kepada seluruh mahasiswa subjek penelitian atas kerja sama yang sangat baik dalam berpartisipasi selama kegiatan penelitian.

\section{DAFTAR PUSTAKA}

Amti, Erman \& Prayitno (2013). Dasar-Dasar Bimbingan dan Konseling. Jakarta: PT. Renika Cipta.

Arikunto, Suharsimi., et al., (2013). Penelitian Tindakan Kelas. Jakarta: Bumi Aksara

Anderson, W Lorin, David R. Krathwohl, Peter W. Airasian, Kathleen A. Cruikshank, Richard E. Ma Ver, Paul R. Pintrich, .James Raths, Merlin C. ... Wittrock. (2001). A Taxonomy for Learning, Teaching, and Assessing. A Revision Of Bloom's. Taxonomy of Educational Objectives Abridged Edition. by Addison Wesley Longman, Inc. New York San Francisco Boston.

Bilge, Yildiz. (2017: 72-100). The effect of Group Counseling Program on Dealing with School Exhaustion of 7 th Grade Students. Journal of Education and Practice. 8 (24). ISSN 2222-1735 (Paper) ISSN 2222-288X (On line).

Carkhuff, R. R. (1917). The Skills of Helping: An Introduction to Counseling Skills. Oxford, England: Human Resource Development Press.

Heny, Purwanita, NW., N Dantes, \& N M Setuti. (2018). Penerapan Bimbingan Kelompok Untuk Meningkatkan Motivasi Belajar Siswa Yang Mengalami Kesulitan Belajar Di Kelas Vii C Smp Negeri 3 Singaraja. Jurnal Bimbingan Konseling Undiksa.

Irawan Mirza, (2017). Proceeding Seminar dan Lokakarya nasional Revitalisasi Laboratorium dan JurnalImiah Dalam Implementasi Kurikulum Bimbingan dan Konseling Berbasis KKNI, 4-6 Agustus 2017. Malang Jawa Timur, Indonesia. 
Ivey, A. E., Ivey, M. B. \& Zalaquett, C. P. (2018). Intentional Interviewing and Counseling: Facilitating Client Development in a Multicultural Society.Belmont, A: Brooks/Cole Publishing Company.

Meiske Puluhulawa, Moh Rizki Djibran, \& Mohamd Rizal Pautina (2017). Layanan Bimbingan kelompok Pengaruhnya Terhadap Self Esteem Siswa. Proceeding Seminar dan Lokakarya Nasional Revitalisasi Laboratorium dan Jurnal Ilmiah dalam Implementasi Kurikulum Bimbingan danKonseling berbasis KKNI, 4-6 Agustus 2017, Malang.

McNiff, Jean and Whitehead, Jack (2011). Action Research Living Theory 2nd edition. SAGE Publication

McAlpine, M. \& Hesketh, I. (2003). Multiple response questions - Allowing for chance in authentic assessment. Paper presented at the 7th International CAA Conference, Leicestershire, United Kingdom.

Muhamed Ayyyub, Bibi Jan. 30 (2011). Effect of Group Gudance Programme on Managing Transiton in Scondary School. SciVerse Science Direct. Procedia Social and Behavioral Sciences. Publihesd by Elsevier Ltd.Open acces under CC by-NCND License.

Nindia Harnes Prima Aidha (2014). Penerapan Bimbingan Kelompok Dengan Teknik Diskusi Kelompok Untuk Meningkatkan Motivasi Belajar Siswa Kelas Viii D Smp Negeri 1 Ngariboyo. Jurnal BK Unesa.

Muliati, Sri (2019). Social Cognitive Theory: Bandura Thougt Review Published in 1982-2012. Journal PSIKODIMENSIA.Vol.18.No 1. JanuariJuni 2019. ISSN Cetak: 6073. DOI. 10.24167/pisidim.v18i1.1708.

Pranoto, H. Atieka N, Fajarwati, R. \& Septora (2018). Layanan Bimbingan Kelmpok dengan Teknik Self-Regulation Untuk Meningkatkan Motivasi belajar Mahasiswa. Indonesian Journal of Educational Counseling, 2 (1) 87- 112).https://doi.org/10.30653/001.201821 .24.Vol.2.Number 1 .

Wibowo. Mungin. Eddy. (2005). Konseling Kelompok Perkembangan. Semarang:

Rahmawati, A. H. (2016). Peningkatan Keterampilan Konseling Konselor Sebaya Pusat Informasi dan Konseling Remaja MAN Yogyakarta. E-Journal Bimbingan dan Konseling. 4 (5). p.1-12.(Online: ttp://journal.student.uny.ac.id/ojs/index.p hp/fipbk/article/download/1147/1021).

Rai Indrayasa, Made. (2012). Penerapan Bimbingan Kelompok Dalam Rangka Meningkatkan Sikap Kepemimpinan Pada Siswa Kelas VII-1 SMP Laboratorium Undiksha Singaraja Tahun Pelajaran 2012/2013. Thesis (tidak diterbitkan). Jurusan BK FIP Undiksha.

Setiawan, H., Oktaviyanti, I., Jiwandono, I. S.., Affandi, L.H., Ermiana, I., \& Khair, B.N. (2020). Analisis Kendala Guru Di SDN Gunung Gatep Kab. Lombok Tengah Dalam Implementasi Pendidikan Inklusif', Didaktis: Jurnal Pendidikan Dan Ilmu Pengetahuan, 20.2 (2020), 169-83. DOI: http://dx.doi.org/10.30651/didaktis.v20i2. $\underline{4704}$

Stringer, Ernest T. (2018). Action Research. Fourth edition. Publisher: SAGE Publications, Inc

Sukmadinata, Nana Syaodih. 2017. Metode Penelitian Pendidikan. Bandung: PT. Remaja Rosdakarya.

Sukmawati, I., Neviyarni., Syukur, N., \& Said, A. (2013). Peningkatan Hasil Belajar Melalui Dinamika Kelompok Dalam Perkuliahan Pengajaran Psikologi Dan Bimbingan Konseling (PPBK). PEDAGOGI:Jurnal Ilmiah Ilmu Pendidikan. XIII (2), p. 10-18. (online: http://ejournal.unp.ac.id/index.php/pedag ogi/article/viewFile/4276/3346).

Sugiyono (2015). Metode Penelitian Kombinasi (Mix Methods). Bandung

Sulis Seetyaningsih, Hary Pasyatoro, \& Endang Ragil (2015). Efektivitas Layanan 
Witono, AH. et al.(2021). Jurnal Ilmiah Profesi Pendidikan, 6 (1): 7 - 13

DOI: https://doi.org/10.29303/jipp.v6i1.132

Bimbingan Kelompok Dalam meningkatkan Hubungan Pertemanan Siswa Kelas VIIIC. Di SMP Negeri 4 Pacitan. Artike Skripsi,FKIP Universitas Nusantara PGRI Kediri. Simki.unpkediri.ac.id.

Tanjung, Yoppy; Budi astute, \& Andika Arisandi (2019: 377-388). Influence of Group Guidance with Discussion Techniques on Local learning Interest. ICMEd. International Conference on Meaningful Education. KnE Social Sciences. Volume 2019.
Winkel. Ws. (2014). Bimbingan dan Konseling di Instansi Pendidikan. Jakarta: Gramedia 